\title{
OPTIMIZATION OF AGRICULTURAL INPUT EFFICIENCY FOR WHEAT PRODUCTION IN CHINA APPLYING DATA ENVELOPMENT ANALYSIS METHOD
}

\author{
WANG, $\mathrm{N}^{1}-\mathrm{JIN}, \mathrm{X} .^{2^{*}}-\mathrm{YE}, \mathrm{S} . \mathrm{T}^{3}-\mathrm{GAO}, \mathrm{Y} .^{4^{*}}-\mathrm{LI}, \mathrm{X} . \mathrm{F}^{5}$ \\ ${ }^{1}$ School of Public Administration, Nanjing University of Information Science and Technology, \\ Nanjing 210000, China \\ ${ }^{2}$ School of Software and Microelectronics, Peking University, Beijing 100000, China \\ ${ }^{3}$ Student Affairs Office, Zhejiang University of Technology; Hangzhou 310000, China \\ ${ }^{4}$ School of Business, Jiangnan University; Wuxi 214122, China \\ ${ }^{5}$ School of Food Science and Technology, Jiangnan University; Wuxi 214122, China \\ *Corresponding author \\ e-mail:wnatwn@163.com \\ (Received 24 ${ }^{\text {th }}$ Oct 2016; accepted $20^{\text {th }}$ Dec 2016)
}

\begin{abstract}
Environment pollution and food security resulting from agricultural input surpluses are of great concern to the world in recent years. Improving use efficiency of agricultural inputs becomes an important way to relieve above issues. For this purpose, five hundred and four small wheat production farmers in Shandong Province of China were selected to be interviewed about their agricultural input costs from different resources, crop yield and other production questions between December 2014 and February 2015. The data collected was applied to evaluate use efficiency and cost saving of agricultural input for wheat production using data envelopment analysis method. The average technical, pure technical and scale efficiency of farmers were $0.69,0.769$ and 0.884 respectively, and $83.7 \%$ of the interviewed farmers were operating at decreasing returns to scale. Efficient farmers in Weifang city could be collected as the benchmark for other ones. The total target input costs could decrease by $16.6 \%$ with respect to the initial input costs, fertilizer, seeds and drainage-irrigation make much greater contributions to the total cost savings. The productivity in target was $16.35 \mathrm{~kg} \mathrm{~S}^{-1}$ increasing by $19.6 \%$ if the recommendations were accepted by farmers in this study. Finally related suggestion was put forward to future government policies and improve farmers' producing style.
\end{abstract}

Keywords: environmental pollution; input surplus; agriculture; technical efficiency; farmer; wheat production

\section{Introduction}

Agricultural input surpluses cause severe environmental pollution and natural resource depletion; thus, the need to improve the utilization efficiency of agricultural inputs has become urgent. Wheat is one of staple crops in the world, especially in developing countries. As a vast agricultural country, China is the largest consumer and producer of wheat. The predominate areas growing wheat are the North China Plains (NCP) and the Yellow-Huai-Hai River Drainage Basin (YHHRDB), where the planting areas account for nearly $70 \%$ of the total wheat areas in China, and winter wheat is planted as a major crop (Wang et al., 2009; Xu et al., 2013). However, the high wheat yield in this region mainly depends on the surplus of agricultural inputs, which has caused serious resource shortage, 
environmental pollution and soil erosion in recent years (Cheng and Han, 1992; Liang et al., 2010; Knowler and Bradshaw, 2007; Li et al., 2001).

Fertilizer is one of dominating inputs boosting the crop productivity, while its use efficiency was only 30-40\%, which is half of the efficiency in developed countries (Zhen et al., 2006; Yan and Gong, 2010). Long-term overuse or misuse of fertilizers not only decrease soil fertility, but also contaminate groundwater (Gao et al., 2006), and some heavy metals or toxic elements could be taken into soil, which aggravates food pollution (Zhong and $\mathrm{Wu}, 2007)$. Also, the total annual consumption of pesticide increases with a high application rate of $14.7 \mathrm{~kg} \mathrm{ha}^{-1}$ (Xiang et al., 2007; Zhang et al., 2003), and fairly large proportion of the applied pesticides being highly toxic are used frequently (Zhong et al., 2000). Although the application of pesticides has retrieved $30 \%$ of the grain loss, about 1.3-1.6 Mha of arable land has been polluted by chemical protection products, and more than $30 \%$ of agricultural products contain pesticide residues (Duan et al., 2016).

Water resource is another important factor influencing crop productivity (Hardin, 2008; Zhang et al., 2006; Fischer et al., 2007). The irrigated lands produce $75 \%$ of grain production for its huge population in China (Peng et al., 2015; Xiong et al., 2010). However, as income rising, people consume more meat, which means more demands of feed grain and water. Fast-growing of the cities and industries also facilitate water consumption and water pollution (Kirby et al., 2003). Additionally, as improving of the irrigation and fertility condition, farmers apply too many seeds, crops become more susceptible to lodging and low efficiency of photosynthesis causing low output ( $\mathrm{Yu}$, 1987; Zhang et al., 2006). Therefore, to maintain grain supplement stably and safely, it is critical to improve the utilization efficiency of agricultural inputs, save resource consumption and ensure food security.

Based on the literature at home and broad, the use efficiency and optimum application of agricultural input for different crops have been evaluated by many researchers applying various methods (Singh et al., 1998, 2004, 2007; Safa and Samarasinghe, 2011; Chauhan et al., 2006). Among all the methods, data envelopment analysis (DEA), as a non-parametric method, has been applied in agricultural sector. It does not need to assume a production function beforehand and allows to consider multiple inputs and outputs simultaneously. The inefficiency decision making units (DMUs) could be separated from the efficiency ones, and their inefficiency sources and amounts also could be evaluated (Zhang et al., 2009). In a past study, Malana and Malano (2006) applied DEA technique to determine the productive efficiency of irrigated wheat area in Pakistan and India taking irrigation, seed and fertilizer as inputs and the wheat yield as output.

Considering few study is conducted on the use efficiency of agricultural inputs for wheat production in China, the technical, pure technical, and scale efficiency, and the returns to scale of farmers for wheat production are all evaluated; the efficient farmers are ranked according to the cross-efficiency scores; and the optimum savings of agricultural inputs from different resources are also calculated for wheat production in Shandong of China.

\section{Materials and methods}

\section{Study area}

Shandong Province is located on the eastern coast of China, with a total area of $137,800 \mathrm{~km}^{2}$, with $75107.61 \mathrm{~km}^{2}$ cultivated area. It is located between $34^{\circ} 22^{\prime}$ and $38^{\circ} 23^{\prime}$ north and $114^{\circ} 19^{\prime}$ and $122^{\circ} 43^{\prime}$ east, in a temperate zone monsoon climate and 
four distinctive seasons. As a major agricultural province, Shandong is one of the major grain producing areas of China. This region has two main crops grown annually, winter wheat and summer maize, which are 3,525,210 ha and 2,874,213 ha respectively. Its total wheat yield was $22.19 \mathrm{Mt}$ in 2013, being on the top of the ranking in China (CSSB, 2014). However, Shandong faces the highest total pollutant emission/loss of agriculture in the whole country (The Ministry of Environmental Protection of National Bureau of Statistics, 2003), its amount and density of agricultural pollution are very extensive, the farmland is the worst, and land desertification is also serious (Guo et al., 2007; Hou et al., 2016).

\section{Field survey and data analysis}

The data for this study were collected through a questionnaire survey. Agricultural production activities of farmers are conducted in small farm sizes ( 0.5 ha to $0.7 \mathrm{ha}$ ) in China uniquely, thus the smallholder household was selected to analysis in this study, and head of the household was interviewed. A multi-stage random sampling method was applied to fix households, 5 cities in Shandong Province, 4 counties in each city were located firstly, and then towns, villages and smallholder householders, respectively. A total of 504 farming households were chosen to participate in this research during the winter holiday (December 2014 to February 2015).

The interviewed farmers often have a low education level, so they could remember the total costs of each agricultural input more easily and exactly, and they do not hire workers generally due to their small land scales. Therefore, the agricultural input costs $\left(\$ \mathrm{ha}^{-1}\right)$ including fertilizer, medicine, seeds, machine and drainage-irrigation were selected as input variables, machine costs include the costs of machinery and diesel fuel, and drainage-irrigation costs include the costs of water for irrigation and electricity; the wheat yield value $\left(\mathrm{kg} \mathrm{ha}^{-1}\right)$ is defined as output variable; each farmer is called as a DMU (Table 1). One-way ANOVA was performed with SPSS (Version 13.0, SPSS Inc., Chicago, IL, USA), followed by Fisher's least significant difference (LSD) to verify significant differences between different sampling zones; the DEA SolverPRO4.1 (release 4.1, SAITECH Inc., Holmdel, NJ, USA) was used to analyse use efficiency of agricultural inputs; the MATLAB (Version 13.0, MathWorks Inc., Natick, MA, USA) was applied to determine the cross-efficiency of the efficient farmers.

Table 1. Statistic analysis of output and major input costs used for wheat production

\begin{tabular}{lcccc}
\hline Item & Average & SD & Min & Max \\
\hline 1. Input $\left(\$\right.$ ha $\left.^{-1}\right)$ & & & & \\
Fertilizer & 410.40 & 82.80 & 119.85 & 1966.76 \\
Medicine & 55.84 & 31.21 & 11.45 & 505.75 \\
Seeds & 216.71 & 42.70 & 4.72 & 877.97 \\
Machine & 341.51 & 93.92 & 16.78 & 2124.11 \\
Drainage-irrigation & 160.72 & 45.88 & 4.39 & 531.03 \\
Total input costs & 1185.18 & 296.51 & 157.18 & 6005.62 \\
2. Output $\left(\mathrm{kg} \mathrm{ha}^{-1}\right)$ & & & & \\
Wheat & 2954.59 & 95.59 & 3611.10 & 11842.05 \\
\hline
\end{tabular}

\section{Model analysis}

Data envelopment analysis (DEA) could adjust inputs of different scales and present results clearly, thus comparing efficient and inefficient DMUs is very easy (Charnes et 
al., 1978; Zhang et al., 2009). An inefficient unit can be improved as a target by reducing the input level with a fixed output (input oriented), or by increasing the output with a fixed input (output oriented). Choosing the individual orientation hinges on the characteristics of the DMUs in the study. In our study, it was possible to control inputs more easily than outputs, thus the input oriented approach was deemed to be appropriate, so the technical, pure technical, scale efficiencies and the returns to scale of wheat production were analysed from input-oriented DEA perspectives in this study according to the method of Nassiri and Singh (2009).

The technical efficiency, which is a global efficiency, can be measured by the ratio of the sum of the weighted outputs to the sum of the weighted inputs and can be expressed as follows:

$$
\mathrm{TE}_{j}=\frac{u_{1} y_{1 j}+u_{2} y_{2 j}+\cdots+u_{n} y_{n j}}{v_{1} x_{1 j}+v_{2} x_{2 j}+\cdots+v_{n} x_{n j}}=\frac{\sum_{r=1}^{n} u_{r} y_{r j}}{\sum_{s=1}^{m} v_{s} x_{s j}}
$$

where $x$ and $y$ represent the input and output and $v$ and $u$ are the input and output weights, respectively, $s$ is the number of inputs $(s=1,2, \ldots m), r$ is the number of outputs $(r=1,2, \ldots n), j$ denotes $\mathrm{j}^{\text {th }}$ DMUs $(j=1,2, \quad k)$, and TE $j$ is the technical efficiency score of $j^{\text {th }}$ DMUs, the value of which is between zero and one. The technical efficiency score could be evaluated by the CCR model introduced by Charnes et al. (1978).

Banker et al. (1984) improved the CCR model to contain both technical and scale efficiency, called the BCC model; the technical efficiency in the BCC model is called the pure technical efficiency, which is calculated under variable returns to scale conditions. The technical efficiency can be calculated by the following relationship:

Technical efficiency $=$ Pure technical efficiency $\times$ Scale efficiency

The DEA models separate the DMUs into efficient and inefficient DMUs, and the inefficient DMUs could be ranked according to their efficiency scores. The efficiency DMUs can be ranked through the cross-efficiency ranking method, which is developed by Sexton et al. (1986). In this method, the DEA efficiency scores can be aggregated in a cross-efficiency matrix $E_{\mathrm{ij}}$, the element in the $\mathrm{i}^{\text {th }}$ row and $\mathrm{j}^{\text {th }}$ column denotes the efficiency score for the $\mathrm{j}^{\text {th }}$ farmer caculated by the optimal weights of the $\mathrm{i}^{\text {th }}$ farmer according to the CCR model.

In the last part of this study, the economic analysis of wheat production is evaluated based on the present condition. The total cost of production is composed of variable cost and fixed cost, which do not include the costs of human labour and farm land rent according to Cheng (2011). The variable costs of wheat production including the costs of fertilizer, medicine, seeds, machine and drainage-irrigation are defined as controllable inputs, while the fixed costs including depreciation charges of fixed assets, premium, administrative cost, financial expense and sale charge are defined as uncontrollable inputs. Some economic indicators such as total production value, total cost of production gross return, net return, productivity were all evaluated as follows:

$$
\text { Total production value }\left(\$ \mathrm{ha}^{-1}\right)=\text { sale price }\left(\$ \mathrm{~kg}^{-1}\right) * \text { yield }\left(\mathrm{kg} \mathrm{ha}^{-1}\right)
$$

Gross return $\left(\$ \mathrm{ha}^{-1}\right)=$ total production value $\left(\$ \mathrm{ha}^{-1}\right)$ - variable costs $\left(\$ \mathrm{ha}^{-1}\right)(\mathrm{Eq} .4)$ 
Net return $\left(\$ \mathrm{ha}^{-1}\right)=$ total production value $\left(\$ \mathrm{ha}^{-1}\right)-$ total costs $\left(\$ \mathrm{ha}^{-1}\right) \quad$ (Eq.5)

$$
\text { Productivity }\left(\mathrm{kg} \$^{-1}\right)=\text { yield }\left(\mathrm{kg} \mathrm{ha}^{-1}\right) / \text { total costs }\left(\$ \mathrm{ha}^{-1}\right)
$$

\section{Results and discussion}

\section{The technical, pure technical and scale efficiency of the interviewed farmers}

Results obtained by the application of the input-orientated BBC and CCR model are illustrated in Fig. 1. 48 and 82 farmers had the technical and pure technical efficiency scores of one, and they were recognized as technically and pure technically efficient farmers respectively; 48 farmers had scale scores of one indicating that they were efficient in productive scales. The 48 farmers were globally efficient and operated at the most proper scale size of production which indicates that it is no need to reduce potential costs of agricultural inputs, while the reminders of the 43 efficient farmers were only locally efficient because of their improper productive scale size. 82, 72 and 216 farmers had the technically, pure technically and scale efficiency scores in the 0.9-1 range, it denotes that the farmers could produce the same amount of output based on the current level of agricultural inputs when benchmarking the efficient producers with similar characteristics.

As is shown in Fig. 1, 461 (91.4\%) farmers had scale efficiency in 0.7-1 range with $216(42.8 \%)$ farmers being in 0.9-1 range, which denoted that the interviewed farmers have advantageous scale efficiencies with respect to pure technique efficiencies. The average technical, pure technical and scale efficiency of farmers were $0.69,0.769$ and 0.884 respectively, implying that many interviewed farmers could not apply productive techniques properly, and there still is great space to enhance their input cost efficiencies. These results are consistent with that of Chauhan et al. (2006), they evaluated the technical, pure technical and scale efficiencies of paddy farmers as 0.7720, 0.9249 and 0.8302 respectively in India. Also, Mohammadi et al. (2011) show that the above three efficiencies for apple production were $0.7857,0.8982$ and 0.8666 separately.

The technical efficiency distribution in different sampling zones was illustrated in Table 2 . The average technical efficiency score $(0.793)$ in Weifang city was higher than that of other sampling cities obviously at 5\% confidence level, the number of efficient farmers was 29 being the most among all sampling zones, and the distribution of technical efficiencies in this region was partial to the 1 side. Farmers in Dezhou city had the lowest average score of technical efficiency as 0.633 , and their distribution of technical efficiencies leaned to the 0.5 side.

The sampling cities with lower technical efficiency may tend to consume more inputs but gain less crop yield. As surveyed in our research, the interviewed farmers in Dezhou consumed $445.50 \$ \mathrm{ha}^{-1}(31.2 \%)$ more than the farmers in Weifang with only increase of $378.45 \mathrm{~kg} \mathrm{ha}^{-1}(5.27 \%)$ in wheat yield, which were consistent with the research of Nassiri and Singh (2009) for paddy crop production in Punjab (India). The results also denoted that the sampling city with low average technical efficiency score may face more serious agricultural pollution and food safety risks. Take Dezhou for example, its application of fertilizer and pesticide have been above average level of Shandong Province since 2005, and all water quality monitoring sections are worse than Grade V due to excessive Chemical Oxygen Demand (COD) and ammonia nitrogen (Zhu, 2013), even the Qihe County in Dezhou is listed as a key point to monitor agricultural non-point source pollution. 


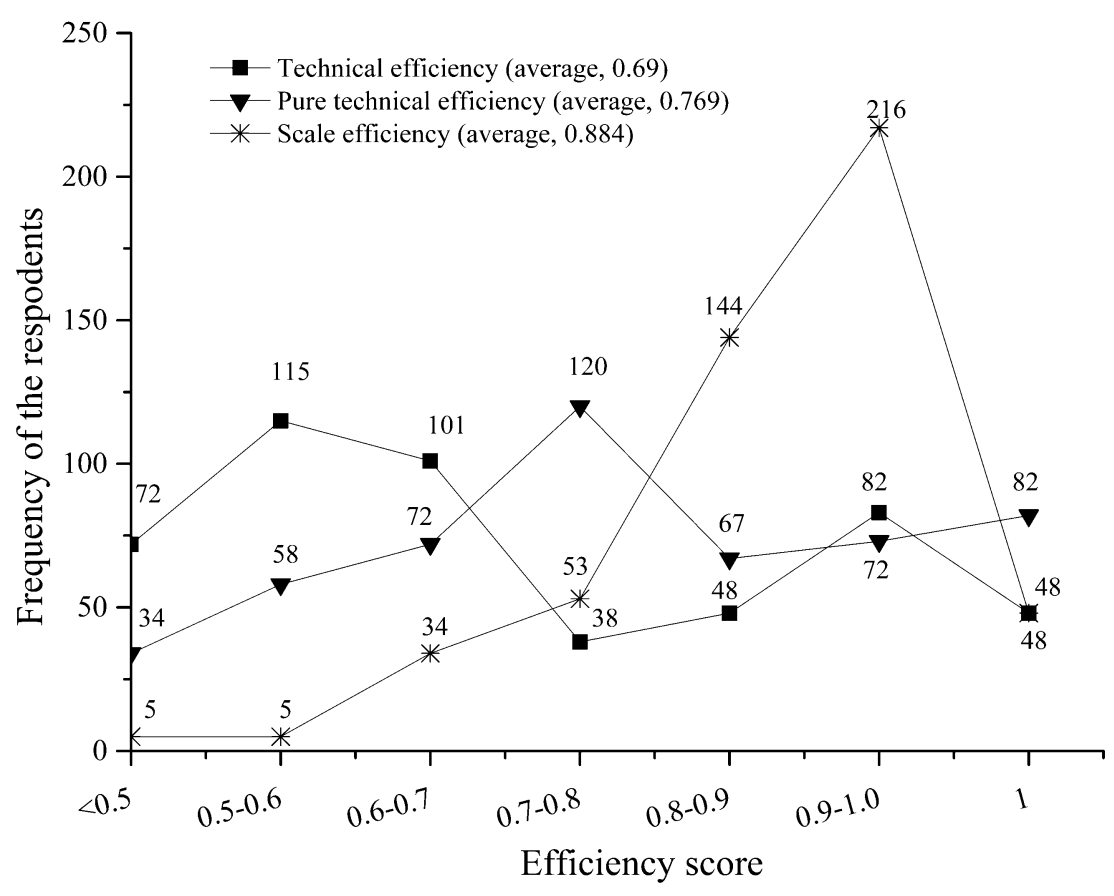

Figure 1. Frequency distribution and average score of technical, pure technical and scale efficiencies for wheat producers $(n=504)$

Table 2. Frequency distribution and average score of technical scale efficiencies in different sampling cities for wheat producers $(n=504)$

\begin{tabular}{lcccccc}
\hline \multirow{2}{*}{\multicolumn{2}{c}{ Distribution }} & \multicolumn{5}{c}{ Sampling cities } \\
\cline { 3 - 7 } & & Dezhou & Jining & Linxi & Weifang & Yantai \\
\hline Efficient & 1 & 10 & 0 & 5 & 29 & 5 \\
& $>0.9$ & 10 & 24 & 15 & 10 & 24 \\
& $0.8-0.9$ & 5 & 0 & 19 & 10 & 14 \\
Inefficient & $0.7-0.8$ & 10 & 5 & 0 & 10 & 14 \\
& $0.6-0.7$ & 24 & 19 & 29 & 14 & 14 \\
& $0.5-0.6$ & 19 & 43 & 19 & 24 & 10 \\
Average & $<0.5$ & 29 & 5 & 14 & 0 & 24 \\
& & $0.633^{\mathrm{a}}$ & $0.666^{\mathrm{a}}$ & $0.681^{\mathrm{a}}$ & $0.793^{\mathrm{b}}$ & $0.684^{\mathrm{a}}$ \\
\hline
\end{tabular}

Note: Different letters show significant difference of means at $5 \%$ level.

\section{Results of returns to scale}

As shown in Table 3, $422(83.7 \%)$ farmers were found to be operating at decreasing returns to scale (DRS), $62(12.3 \%)$ were at constant returns to scale (CRS) and only 20 (3.97\%) farmers were at increasing returns to scale (IRS). All inefficient farmers in Dezhou and Linyi were operating at DRS, while only 5, 10 and 5 farmers in Jining, Weifang and Yantai were operating at IRS respectively. Therefore, it is necessary to reduce the scales of agricultural inputs for these farmers. Meanwhile the land scale management should be further implemented to improve marginal productivity of arable lands. The forms of land scale operation mainly include scientific and technological 
demonstration area, large scale farmers and economic cooperation in agriculture in China. Supported by government, transaction areas achieved 32002 ha being $4.74 \%$ of the total arable areas in 2009 in Weifang, which advances agricultural development positively.

Table 3. The returns to scale of the interviewed farmers in different sampling zones in Shandong, China $(n=504)$

\begin{tabular}{cccccccc}
\hline \multirow{2}{*}{ Returns to scale } & \multicolumn{5}{c}{ Sampling zones } & \multirow{2}{*}{ Total } \\
\cline { 2 - 6 } & Dezhou & Jining & Linxi & Weifang & Yantai & \\
\hline Increase & 0 & 5 & 0 & 10 & 5 & 20 \\
Constant & 14 & 0 & 10 & 28 & 10 & 62 \\
Decrease & 96 & 86 & 91 & 58 & 91 & 422 \\
Total number of respondents & 110 & 91 & 101 & 96 & 106 & 504 \\
\hline
\end{tabular}

\section{Cross efficiency analysis}

To identify the best operating practices among the technically efficient farmers, the cross efficiency matrix based on CCR model is calculated. As is shown in Table 4, the farmers located in Weifang had much higher cross efficiency scores than that of other cities, for example, the scores of farmers with serial number 310, 391, 343, 378 and 308 were $0.905,0.879,0.869,0.841$ and 0.807 respectively. Whereas, the cross efficiency scores of farmers in Dezhou were the lowest in all sampling cities in Shandong Province, and were only $0.353,0.311,0.288$ and 0.258 respectively. Thus, the practices adopted by the farmers in Weifang could benchmark other inefficient ones, and the wheat production practices in the sampling zone of Weifang can also guide other zones in Shandong Province.

Table 4. Cross-efficiency score for 48 efficient farmers base on the CCR model

\begin{tabular}{cccccccc}
\hline $\begin{array}{c}\text { Farmer } \\
\text { number }\end{array}$ & Cross-efficiency & Order Location & $\begin{array}{c}\text { Farmer } \\
\text { number }\end{array}$ & Cross-efficiency & Order & Location \\
\hline 310 & 0.905 & 1 & Weifang & 344 & 0.611 & 25 & Weifang \\
391 & 0.879 & 2 & Weifang & 322 & 0.606 & 26 & Weifang \\
343 & 0.869 & 3 & Weifang & 325 & 0.602 & 27 & Weifang \\
378 & 0.841 & 4 & Weifang & 432 & 0.594 & 28 & Yantai \\
308 & 0.807 & 5 & Weifang & 315 & 0.589 & 29 & Weifang \\
400 & 0.781 & 6 & Yantai & 381 & 0.578 & 30 & Weifang \\
435 & 0.779 & 7 & Yantai & 421 & 0.569 & 31 & Yantai \\
412 & 0.764 & 8 & Yantai & 456 & 0.554 & 32 & Yantai \\
327 & 0.745 & 9 & Weifang & 448 & 0.532 & 33 & Yantai \\
356 & 0.731 & 10 & Weifang & 7 & 0.519 & 34 & Jining \\
377 & 0.707 & 11 & Weifang & 377 & 0.482 & 35 & Weifang \\
332 & 0.693 & 12 & Weifang & 12 & 0.474 & 36 & Jining \\
375 & 0.680 & 13 & Weifang & 417 & 0.457 & 37 & Yantai \\
368 & 0.678 & 14 & Weifang & 501 & 0.435 & 38 & Yantai
\end{tabular}




\begin{tabular}{cccccccc}
321 & 0.666 & 15 & Weifang & 128 & 0.400 & 39 & Linyi \\
342 & 0.657 & 16 & Weifang & 45 & 0.387 & 40 & Jining \\
385 & 0.650 & 17 & Weifang & 57 & 0.382 & 41 & Jining \\
383 & 0.649 & 18 & Weifang & 169 & 0.381 & 42 & Linyi \\
351 & 0.623 & 19 & Weifang & 112 & 0.377 & 43 & Linyi \\
329 & 0.622 & 20 & Weifang & 157 & 0.362 & 44 & Linyi \\
309 & 0.620 & 21 & Weifang & 217 & 0.353 & 45 & Dezhou \\
492 & 0.617 & 22 & Yantai & 233 & 0.311 & 46 & Dezhou \\
476 & 0.613 & 23 & Yantai & 267 & 0.288 & 47 & Dezhou \\
451 & 0.611 & 24 & Yantai & 288 & 0.258 & 48 & Dezhou \\
\hline
\end{tabular}

\section{Differences of input costs and output between efficient and inefficient farmers}

Table 5 shows that inefficient farmers consumed the costs of agricultural inputs from different resources in higher quantity than that of efficient ones, while wheat yield was in lower quantity. The main factors with much higher difference amounts were fertilizer, machine and drainage-irrigation as $136.58,86.22$ and $67.59 \$$ ha $^{-1}$, while the factors with much higher difference rates were medicine, drainage-irrigation and fertilizer with $46.1 \%, 40.4 \%$ and $32.3 \%$ respectively. The wheat yields of inefficient farmers were $411.90 \mathrm{~kg} \mathrm{ha}^{-1}$ lower than that of efficient farmers with the difference rate being $5.9 \%$. Thus it is indicated improper input mix or scale in production could cause low output. Zhen et al. (2006) studied the soil fertility management practices in North China Plain, the results showed that the optimum does of $\mathrm{N}, \mathrm{P}, \mathrm{K}$ application recommended for wheat are 255, 120, and $9 \mathrm{~kg} \mathrm{ha}^{-1}$ separately. In other researches, Jiang et al. (2006) and Manna et al. (2007) stated that the combination of NPK fertilizers and farmyard manure could increase wheat yield without deteriorating land quality. Xu et al. (2013) showed that overuse of seeds would lead to severe lodging and imbalance of carbon and nitrogen metabolism causing a high susceptibility to lodging in return; significantly reduced and excessive irrigation may limit the $\mathrm{N}$ contribution of pre-anthesis vegetative parts to grains (Xu et al., 2005; Meng et al., 2015).

Table 5. Amounts of input costs and output of efficient and inefficient farmers for wheat production

\begin{tabular}{|c|c|c|c|c|}
\hline Inputs & $\begin{array}{l}\text { Efficient } \\
\text { farmers }\end{array}$ & $\begin{array}{c}\text { Inefficient } \\
\text { farmers }\end{array}$ & $\begin{array}{c}\text { Difference amount } \\
\left(\$ \mathrm{ha}^{-1}\right)^{\mathrm{a}}\end{array}$ & $\begin{array}{c}\text { Difference rate } \\
(\%)^{\mathbf{b}} \\
\end{array}$ \\
\hline \multicolumn{5}{|l|}{ 1. Inputs $\left(\$\right.$ ha $\left.^{-1}\right)$} \\
\hline Fertilizer & 286.83 & 423.41 & 136.58 & 32.30 \\
\hline Medicine & 31.46 & 58.41 & 26.95 & 46.10 \\
\hline Seeds & 165.02 & 222.13 & 57.11 & 25.70 \\
\hline Machine & 263.51 & 349.72 & 86.22 & 24.70 \\
\hline Drainage-irrigation & 99.55 & 167.17 & 67.59 & 40.40 \\
\hline \multicolumn{5}{|l|}{ 2. Output $\left(\mathrm{kg} \mathrm{ha}^{-1}\right)$} \\
\hline Wheat yield & 7345.80 & 6933.90 & -411.90 & -5.90 \\
\hline
\end{tabular}

Note: ${ }^{[\mathrm{a}]}$ Difference amounts $\left(\$ \mathrm{ha}^{-1}\right)=$ inefficient farmers - efficient farmers; ${ }^{\text {[b] }}$ Difference rate $(\%)=$ (inefficient farmers - efficient farmers) / inefficient farmers* $100 \%$. 


\section{Optimum savings of agricultural input costs for wheat production}

As is illustrated in Table 6, the target use for fertilizer was the highest as $371.79 \$$ $\mathrm{ha}^{-1}$, following machine $335.28 \$ \mathrm{ha}^{-1}$, seeds $152.53 \$ \mathrm{ha}^{-1}$, drainage-irrigation $91.36 \$$ $\mathrm{ha}^{-1}$, medicine $37.08 \$ \mathrm{ha}^{-1}$; the quantity of cost saving on drainage-irrigation, seeds and fertilizer were much higher with $69.36 \$ \mathrm{ha}^{-1}, 64.17 \$ \mathrm{ha}^{-1}$ and $38.61 \$ \mathrm{ha}^{-1}$, and their shares were $35.2 \%, 32.6 \%$ and $19.6 \%$ separately, while the factors with higher rates of cost saving were drainage-irrigation (43.2\%), medicine $(33.6 \%)$ and seeds $(29.6 \%)$. If the recommendation is followed, the total costs of target use were $988.04 \$ \mathrm{ha}^{-1}$, which was $197.14 \$ \mathrm{ha}^{-1}(16.6 \%)$ higher than that of initial use.

According to the above analysis, the highest quantity and rate of cost saving for drainage-irrigation show that there is a great scope to increase the efficiency of drainage-irrigation application. Winter wheat is generally watered through flood irrigation, but its water use efficiency is very low and the waste of water is extensive (Shao et al., 2009). Additionally, the application of ageing drainage equipment causes excessive consumption of electricity. Thus, promoting new irrigation practices is of importance to increase efficiency of drainage-irrigation, such as sprinkler irrigation (Montazar and Sadeghi, 2008), drip irrigation (Ayars et al., 1999), deficit irrigation (Li et al., 2012), supplemental irrigation treatment regimen (Meng et al., 2015), "20 + 40" furrow planting (Zhao et al., 2013).

Table 6. Input cost savings from different sources and distribution of total cost savings if the target use is achieved

\begin{tabular}{|c|c|c|c|c|c|}
\hline Inputs $\left(\$ \mathbf{h a}^{-1}\right)$ & Initial use & $\begin{array}{c}\text { Target } \\
\text { use }\end{array}$ & $\begin{array}{l}\text { Quantity of cost } \\
\text { saving }\left(\$ \text { ha }^{-1}\right)^{\mathrm{a}}\end{array}$ & $\begin{array}{l}\text { Rate of cost } \\
\text { saving }(\%)^{b}\end{array}$ & $\begin{array}{l}\text { Distribution } \\
\text { of total cost } \\
\text { savings }(\%)^{\mathrm{c}}\end{array}$ \\
\hline Fertilizer & 410.40 & 371.79 & 38.61 & 9.40 & 19.6 \\
\hline Medicine & 55.84 & 37.08 & 18.76 & 33.60 & 9.5 \\
\hline Seeds & 216.71 & 152.53 & 64.17 & 29.60 & 32.6 \\
\hline Machine & 341.51 & 335.28 & 6.23 & 1.80 & 3.2 \\
\hline Drainage-irrigation & 160.72 & 91.36 & 69.36 & 43.20 & 35.2 \\
\hline Total & 1185.18 & 988.04 & 197.14 & 16.60 & $100 \%$ \\
\hline
\end{tabular}

Note: ${ }^{[\mathrm{a}]}$ Quantity of cost saving $\left(\$\right.$ ha $\left.^{-1}\right)=$ initial use - target use; ${ }^{[\mathrm{b}]}$ Rate of cost saving $(\%)=$ (initial use - target use) / initial use* $100 \%$; ${ }^{[c]}$ Distribution of total cost savings = quantity of cost saving from different sources / total quantity of cost saving*100\%

\section{Economic analysis of wheat production}

Table 7 shows that the total production value calculated by Eq. (3) was $2806.89 \$$ $\mathrm{ha}^{-1}$. The variable costs were $1185.18 \$ \mathrm{ha}^{-1}$ and $988.04 \$ \mathrm{ha}^{-1}$, for initial and target conditions. The fixed costs were 17.7 $\$ \mathrm{ha}^{-1}$. Therefore, the total costs were $1005.74 \$$ $\mathrm{ha}^{-1}$ in target condition, and could be saved $16.6 \%$. The gross return and net return increased by $12.3 \%$ to achieve $1818.85 \$ \mathrm{ha}^{-1}$ and $1801.15 \$ \mathrm{ha}^{-1}$ evaluated by Eqs. (4) (5) respectively. The productivity estimated by Eq. (6) was $16.35 \mathrm{~kg}^{-1}$ in target increasing $19.6 \%$. In many past literatures, researchers make the similar analysis to different crop productions. The total production value for apple production was $10179.23 \$ \mathrm{ha}^{-1}$, and productivity value was $2.74 \mathrm{~kg}^{-1}$ with $8.73 \%$ increase (Mohammadi et al., 2011). The productivity was $17.04 \mathrm{~kg}^{-1}$ for sugar in Tokat 
province of Turkey (Erdal et al., 1998), $4.05 \mathrm{~kg} \$^{-1}$ for kiwifruit in Iran (Mohammadi et al., 2010), $8.71 \mathrm{~kg}^{-1}$ for potato in Ardabil province of Iran (Mohammadi et al., 2008), $3.69 \mathrm{~kg} \$^{-1}$ for canola production in Turkey (Unakitan et al., 2010).

Table 7. Economic analysis of wheat production in Shandong, China

\begin{tabular}{lccc}
\hline \multicolumn{1}{c}{ Items of cost and return } & $\begin{array}{c}\text { Quantity in } \\
\text { initial }\end{array}$ & $\begin{array}{c}\text { Quantity in } \\
\text { target }\end{array}$ & Difference rate $(\%)^{\mathbf{b}}$ \\
\hline Yield $\left(\mathrm{kg} \mathrm{ha}^{-1}\right)$ & 6973.20 & 6973.20 & - \\
Sale price $\left(\$ \mathrm{~kg}^{-1}\right)$ & 4.07 & 4.07 & - \\
Total production value $\left(\$ \mathrm{ha}^{-1}\right)$ & 2806.89 & 2806.89 & - \\
Variable costs $\left(\$ \mathrm{ha}^{-1}\right)$ & 1185.18 & 988.04 & 16.6 \\
Fixed costs $\left(\$ \mathrm{ha}^{-1}\right)^{\mathrm{a}}$ & 17.70 & 17.70 & - \\
Total costs $\left(\$ \mathrm{ha}^{-1}\right)$ & 1202.88 & 1005.74 & 16.6 \\
Gross return $\left(\$ \mathrm{ha}^{-1}\right)$ & 1621.71 & 1818.85 & -12.3 \\
Net return $\left(\$ \mathrm{ha}^{-1}\right)$ & 1604.01 & 1801.15 & -12.3 \\
Productivity $\left(\mathrm{kg}^{-1}\right)$ & 13.65 & 16.35 & -19.6 \\
\hline
\end{tabular}

Note: ${ }^{[a]}$ The data of fixed costs is selected from the assembly of the national agricultural cost-benefit in $2014\left(\right.$ NDRC 2014); ${ }^{[\mathrm{b}]}$ Difference rate $(\%)=$ (quantity in initial - quantity in target $) /$ quantity in initial $\times$ $100 \%$.

\section{Conclusions}

Many farmers in this study could not use agricultural techniques properly, or do not apply them under the optimum quantities and scales, overuse and improper mix of agricultural inputs could cause low yield. $83.7 \%$ of the respondents were operating at DRS, and need to reduce the scales of agricultural input costs. The technically efficient farmers with much higher cross-efficiency scores could be selected to benchmark other ones. Fertilizer, seeds and drainage-irrigation make much greater contributions to total cost savings. The total inputs costs for wheat could decrease by $16.6 \%$, while the productivity could increase by $19.6 \%$, if according recommendations in this study.

The valid path to protect environment and ensure food security are to increase crop productive efficiency though using agricultural inputs properly. Firstly, large-scale management of arable land should be further implemented, based on the land ownership of farmers. Scale management pattern could be selected according to local condition including mechanization, agricultural economics and social service. Secondly, new agricultural technologies or practices should be developed to improve scientific progress, such as formulated fertilization, water-saving irrigation regime, pollution-free and green pesticides and crop varieties with drought, lodging, diseases and pests resistance. As for the technologies or practices which could not bring obvious benefit increase of farmers but urgent to be popularized, government could make full use of WTO green box policies to executive or improve subsidy levels. Finally, the information sources like agricultural extension agents, other farmers and mass media are essential to transmit protective and advanced agricultural information, and special column about related information could be developed in television, books, newspaper, internet and telephone. Additionally, protective agricultural products market needs to be established to provoke farmers' adoption decision through customer demand. 
Acknowledgments. We would like to thank the editor and reviewers for their valuable comments on the manuscript, and the students from the business school at Jiangnan University for their major input on the survey; we would also like to thank the respondents in Shandong Province of China for their help and cooperation. This study was funded by the National Social Sciences Foundation of China (13BJY102) and Soft Science Project of Jiangsu Province (BR2016005).

\section{REFERENCES}

[1] Ayars, J. E., Phene, C. J., Hutmacher, R. B., Davis, K. R., Schoneman, R.A., Vail, S.S., Mead R.M. (1999): Subsurface drip irrigation of row crops: a review of 15 years of research at the Water Management Research Laboratory. - Agricultural Water Management 42(1): 1-27.

[2] Banker, R. D., Charnes, A., Cooper, W. W. (1984): Some models for estimating technical and scale in efficiencies in data envelopment analysis. - Management Science 30: 1078-1092.

[3] Charnes, A., Cooper, W. W., Rhodes, E. (1978). Measuring the efficiency of decision-making units. - The Journal of Productivity Analysis 2: 429-444.

[4] Chauhan, N. S., Mohapatra, P. K., Pandey, K. P. (2006): Improving energy productivity in paddy production through benchmarking-an application of data envelopment analysis. Energ. - Energy Conversion and Management 47(9): 1063-1085.

[5] Cheng, G. Q. (2011): China's agricultural subsidies. - China Development Press, Beijing. (in Chinese)

[6] Cheng, X., Han, C. H. (1992): Sustainable agricultural development in China. - World Development 20: 1127-1144.

[7] China State Statistical Bureau (CSSB) (2014): China statistical yearbook 2014. - China State Statistical Press, Beijing. (in Chinese)

[8] Duan, Y., Guan, N., Li, P. P., Li, J. G., Luo, J. H. (2016): Monitoring and dietary exposure assessment of pesticide residues in cowpea (Vigna unguiculata L. Walp) in Hainan, China. - Food Control 59: 250-255.

[9] Erdal, G., Esengun, K., Erdal, H., Gunduz, O. (1998): Energy use and economical analysis of sugar beet production in Tokat province of Turkey. - Energy 32(1): 35-41.

[10] Fischer, G., Tubiello, F. N., van Velthuizen, F., Wiberg, D. A. (2007): Climate change impacts on irrigation water requirement: effects of mitigation, 1990-2080. - Technol Forecast Social Change 74: 1083-1107.

[11] Gao, C., Sun, B., Zhang, T. L. (2006): Sustainable Nutrient Management in Chinese Agriculture: Challenges and Perspective. - Pedosphere 16: 253-263.

[12] Guo, S. M., Ma, S., Chen, Y. J. (2007): Effect factors on grain product in main grain product areas of China. - Research of agricultural modernization 28: 84-87.

[13] Hardin, L. S. (2008): mMeetings that changed the world. Bellagio 1969: the Green Revolution. - Nature 455: 470-471.

[14] Hou, Z. J., Lu, Z. Q., Liang, J. Z., Chen, C., Xu, Y. (2016): A healthy monitor system for fall and balance detection of elderly. - Journal of Mechanical Engineering Research and Developments 39(2): 364-372.

[15] Jiang, D., Hengsdijk, H., Dai, T. B., de Boer, W., Jing, Q., Cao W. X. (2006): Long-Term Effects of Manure and Inorganic Fertilizers on Yield and Soil Fertility for a Winter Wheat-Maize System in Jiangsu, China. - Pedosphere 16(1): 25-32.

[16] Kirby, R. M., Bartram, J., Carr, R. (2003): Water in food production and processing: quantity and quality concerns. - Food Control 14(5): 283-299.

[17] Knowler, D., Bradshaw, B. (2007): Farmers' adoption of conservation agriculture: A review and synthesis of recent research. - Food Policy 32: 25-48 
[18] Liang, L. T., Feng, S. Y., Qu, F. T. (2010): Forming mechanism of agricultural non-point source pollution: a theoretical and empirical study. - China Population Resources and Environment 20: 74-80. (in Chinese)

[19] Li, Q. Q., Zhou, X. B., Chen, Y. H., Yu, S. L. (2012): Water consumption characteristics of winter wheat grown using different planting patterns and deficit irrigation regime. Agricultural Water Management 105: 8-12.

[20] Li, Y. Y., Jiang, N. H., Guo, Z. X. (2001): Theory of Grain Fluctuation in China. - Chinese Agricultural Press, Beijing. (in Chinese)

[21] Manna, M., Swarup, A., Wanjari, R., Mishra, B., Shahi, D. (2007): Long-term fertilization, manure and liming effects on soil organic matter and crop yields. - Soil and Tillage Research 94: 397-409.

[22] Malana, N. M., Malano, H. M. (2006): Benchmarking productive efficiency of selected wheat areas in Pakistan and India using data envelopment analysis. - Irrigation and drainage 55(4): 383-394.

[23] Meng, W. W., Yu, Z. W., Zhang, Y. L., Yu, S., Wang, D. (2015) Effects of supplemental irrigation on water consumption characteristics and grain yield in different wheat cultivars. - Chilean journal of agricultural research 75(2): 216-223.

[24] Mohammadi, A., Rafiee, S., Mohtasebi, S. S., Mousavi Avval, S. H., Rafiee, H. (2011): Energy efficiency improvement and input cost saving in kiwifruit production using Data Envelopment Analysis approach. - Renewable Energy 36(9): 2573-2579.

[25] Mohammadi, A., Rafiee, S., Mohtasebi, S. S., Rafiee, H. (2010): Energy inputs-yield relationship and cost analysis of kiwifruit production in Iran. - Renewable Energy 35(5): 1071-1075.

[26] Montazar, A., Sadeghi M. (2008): Effects of applied water and sprinkler irrigation uniformity on alfalfa growth and hay yield. - Agricultural Water Management 95(11): 1279-1287.

[27] Mohammadi, A., Tabatabaeefar, A., Shahin, S., Rafiee, S., Keyhani, A. (2008): Energy use and economical analysis of potato production in Iran a case study: Ardabil province. Energy Conversion and Management 49(12): 3566-3570.

[28] Nassiri, S. M., Singh, S. (2009). Study on energy use efficiency for paddy crop using data envelopment analysis (DEA) technique. - Applied Energy 86(7-8): 1320-1325.

[29] National Development and Reform Commission (NDRC) (2014): Assembly of the national agricultural cost-benefit 2014. - China State Statistical Press, Beijing. (in Chinese)

[30] Peng, W. X., Lin, Z., Wang, L. S., Wu, J. G. (2015): Effect of weakly alkaline salt pretreatment on bio-boards for medicine safety. - Journal of Pure and Applied Microbiology 9(3): 1913-1917.

[31] Safa, M., Samarasinghe, S. (2011): Determination and modelling of energy consumption in wheat production using neural networks: "A case study in Canterbury province, New Zealand". - Energy 36(8): 5140-5147.

[32] Sexton, T. R., Silkman, R. H., Hogan, A. J. (1986): Data envelopment analysis: Critique and extensions. - New Directions for Program Evaluation 1986(32): 73-105.

[33] Shao, L. W., Zhang, X. Y., Chen, S. Y., Sun, H. Y., Wang, Z. H. (2009): Effects of Irrigation Frequency under Limited Irrigation on Root Water Uptake, Yield and Water Use Efficiency of Winter Wheat. - Irrigation and Drainage 58(4): 393-405.

[34] Singh, S., Singh, S., Mittal, J. P., Pannu, C. J. S. (1998): Frontier energy use for the cultivation of wheat crop in Punjab. - Energy Conversion and Management 39(5-6): 485-491.

[35] Singh, G., Singh, S., Singh, J. (2004): Optimization of energy inputs for wheat crop in Punjab. - Energy Conversion and Management 45(3), 453-465.

[36] Singh, H., Singh, A. K., Kushwaha, H. L., Singh, A. (2007): Energy consumption pattern 
of wheat production in India. Energy 32(10): 1848-1854.

[37] The ministry of environmental protection of the national bureau of statistics. (2013): China statistical yearbook on environment 2013. - China Statistics Press, Beijing. (in Chinese)

[38] Unakitan, G., Hurma, H., Yilmaz, F. (2010): An analysis of energy use efficiency of canola production in Turkey. - Energy 35(9): 3623-3627.

[39] Wang, F. H., He, Z. H., Sayre, K., Li, S. D., Si, J. S., Feng, B., Kong, L. G. (2009): Wheat cropping systems and technologies in China. - Field crops research 111(3): 181-188.

[40] Xiang, P., Zhou, Y., Huang, H., Zheng, H. (2007): Discussion in the green tax stimulation measure of nitrogen fertilizer non-point source pollution control: using the Dongting Lake area. - Agricultural Sciences in China 40: 330-337.

[41] Xiong. W., Holman, I., Lin, E., Conway, D., Jiang, J. H., Xu, Y. L, Li, Y. (2010): Climate change, water availability and future cereal production in China. - Agriculture Ecosystem and Environment 135: 58-69.

[42] Xu, Z. Z., Yu, Z. W., Wang, D., Zhang, Y. L. (2005): Nitrogen accumulation and translocation for winter wheat under different irrigation regimes. - Journal of Agronomy and Crop Science 191(6): 439-449.

[43] Xu, Z. Z., Yu, Z. W., Zhao, J. Y. (2013): Theory and application for the promotion of wheat production in China: past, present and future. - Journal of the Science of Food and Agriculture 93(10): 2339-2350.

[44] Yan, X. Y., Gong, W. (2010): The role of chemical and organic fertilizers on yield, yield variability and carbon sequestration- results of a 19-year experiment. - Plant and Soil 331(1-2): 471-480.

[45] Yu, S. L. (1987). Precision Seedling Cultivation for High Yield of Winter Wheat. - China Agricultural Press, Beijing. (in Chinese)

[46] Zhao, D. D., Shen, J. Y., Lang, K., Liu, Q. R., Li, Q. Q. (2013): Effects of irrigation and planting patterns on radiation use efficiency and yield of winter wheat in North China. Agricultural Water Management 118: 87-92.

[47] Zhang, X. K., Yang, S. J., Zhou, Y., He, Z. H., Xia, X. C. (2006): Distribution of the Rht-B1b, Rht-D1b and Rht8 reduced height genes in autumn-sown Chinese wheat detected by molecular markers. - Euphytica 152: 109-116.

[48] Zhang, X., Huang, G. H., Lin, Q., Yu, H. (2009): Petroleum-contaminated groundwater remediation systems design: A data envelopment analysis based approach. - Expert Systems with Applications 36(3, Part 1): 5666-5672.

[49] Zhang, Z. Y., Shi, Z., Zhou, Q. (2003): Impacts of agrochemical on entironment \& human health and relevant strategies. - Journal of China Agricultural University 8: 73-77. (in Chinese)

[50] Zhen, L., Zoebisch, M. A., Chen, G., Feng, Z. (2006): Sustainability of farmers' soil fertility management practices: A case study in the North China Plain. - Journal of Environmental Management 79: 409-419.

[51] Zhong, W. K., Hao, J., Kong, M. X., Chen, Y. L. (2000): Pesticides residues in food in China. - Pesticide 39: 1-4.

[52] Zhong, X. M., Wu, X. P. (2007): Present status, existing problems and counter measures of farmland pollution and quality and safety of agricultural products in China. - Chinese Journal of Agricultural Resources and Regional Planning 28: 27-32. (in Chinese)

[53] Zhu, C. R. (2013): Research on non-point source pollution in Dezhou. - Economics and Trade Update 11: 151-152. (in Chinese) 